Brit. med. F., 1966, 1, 1433.

Carstairs, K., C., Breckenridge, A., Dollery, C. T., and Worlledge, S. M. (1966). Lancet, 2, 133 .

Chaplin, H., jun., and Mollison, P. L. (1952). Blood, 7, 1227

Chaplin, H., jun., and Molison, P. L.

Comty, C. M., Baillod, R. A., and Shaldon, S. (1965). Proc. Europ.

Dialysis Transplant Ass., 2, 88.

Desforges, J. F., and Dawson, J. P. (1958). Arch. intern. Med., 101, 326. Giovannetti, S., Balestri, P. L., and Cioni, L. (1965). Clin. Sci., 29, 407 et al.' (1963). Minerva nefrol., 10, 226.

Gomori, G. (1942). 7. Lab. clin. Med., 27, 955.

Hulme, B., and Hardwicke, J. (1966). Proc. roy. Soc. Med., 59, 509.
Joske, R. A., McAlister, J. M., and Prankerd, T. A. J. (1956). Clin. Sci., 15, 511 .

Loge, J., P., Lange, R. D., and Moore, C. V. (1958). Amer. F. Med., 24,4 .

Muirhead, E. E., and Jones, F. (1963). Blood, 22, 272.

Ragen, P. A., Hagedorn, A. B., and Owen, C. A. (1960). Arch. intern. Med., $105,518$.

Turnbull, A., Hope, A., and Verel, D. (1957). Clin Sci., 16, 389.

Veall, N., and Vetter, H. (1958). Radioisotope Techniques in Clinical Research and Diagnosis, p. 233 . London.

Verel, D., Turnbull, A., Tudhope, G. R., and Ross, J. H. (1959). Quart. F. Med., 28, 491 .

\title{
Dissolution of Cystine Stones During D-Penicillamine Treatment of a Pregnant Patient with Cystinuria
}

\author{
J. C. CRAWHALL, * PH.D., M.B., B.S. ; E. F. SCOWEN,* M.D., D.SC., F.R.C.P., F.R.C.P.ED., F.R.C.S., F.C.PATH. \\ C. J. THOMPSON,* M.A. ; R. W. E. WATTS,* M.D., PH.D., M.R.C.P.
}

[With Special Plate]

Brit. med. F., 1967, 2, 216-218

Crawhall, Scowen, and Watts (1963) reported that D-penicillamine reduced the excretion of cystine in cystinuria, and that the more soluble cysteine-penicillamine disulphide was excreted in the urine. The use of $\mathrm{D}$-penicillamine to prevent urolithiasis in cystinuria was suggested on the basis of these results (Crawhall et al., 1963), which have now been confirmed in several laboratories (Crawhall, Scowen, and Watts, 1964 ; Lotz and Potts, 1964 ; King and Boyce, 1965 ; Crawhall and Thompson, 1965). The relative merits of D-penicillamine treatment and of the regimen which consists of promotion of a vigorous water diuresis throughout the 24 hours, recommended by Dent and Senior (1955) and Dent, Friedman, Green, and Watson (1965), requires long-term evaluation. There have already been reports of encouraging results in short-term studies with D-penicillamine (Crawhall, Scowen, and Watts, 1964 ; Lotz and Bartter, 1965 ; Bartter, Lotz, Thier, Rosenberg, and Potts, 1965 ; McDonald and Henneman, 1965).

The present paper records briefly the case of a patient whose stones had disappeared completely and asymptomatically after 18 months' continuous D-penicillamine treatment, during which time she became pregnant and gave birth to a normal child.

\section{Case Report}

The patient's first urinary symptoms were an attack of right loin pain and increased frequency of micturition when she was 12 years old. These symptoms subsided spontaneously after a few days, and she remained well until August 1963, when, at the age of 18, she had a sudden attack of severe pain in the right loin, associated with increased frequency of micturition and macroscopic haematuria, which lasted for about one day. Attacks of similar pain recurred, and she was referred to St. Bartholomew's Hospital in September 1963. She also gave a history that her only sib (a brother aged 21 ) had had an attack of pain similar to renal colic, and he has been shown to be a homozygous cystinuric (Patient No. 5, Crawhall, Saunders, and Thompson, 1966).

There were no abnormal findings on physical examination ; bloodpressure was $105 / 85$, height 59 in. $(150 \mathrm{~cm}$.), weight 7 stone $12 \mathrm{lb}$. $(50 \mathrm{~kg}$.). The urinary centrifuged deposit contained erythrocytes, pus cells, and cystine crystals ; urine culture gave a scanty growth of Escherichia coli. The cyanide-nitroprusside test (Lewis, 1933) for excessive urinary cystine was positive, and increased amounts of lysine, ornithine, and arginine were also present. The right kidney contained multiple radio-opaque calculi (Special Plate, Fig. 1), it

\footnotetext{
* Medical Professorial Unit (Dunn Laboratories), St. Bartholomew's
} Hospital, London. was hydronephrotic, and its ability to excrete sodium diatrizoate was impaired.

The patient was admitted for further study in December 1963, when the following additional observations were made: haemoglobin $13 \mathrm{~g} . / 100 \mathrm{ml}$.; leucocyte count 4,000/c.mm., with normal differential count; blood urea $34 \mathrm{mg} . / 100 \mathrm{ml}$.; quantitative urine culture 100,000 organisms/ml. Mean urinary cystine excretion determined gravimetrically (Crawhall et al., 1963) $719 \mathrm{mg}$. (S.D.= $120 ; 8$ observations) $/ 24$ hr. or 664 mg. (S.D. $=156 ; 8$ observations)/g. creatinine; and $733 \mathrm{mg}$. (S.D. $=113 ; 9$ observations)/ $24 \mathrm{hr}$. or $666 \mathrm{mg}$. (S.D. $=108 ; 9$ observations)/g. creatinine when determined by the 5,5'-dithiobis-(2-nitrobenzoic acid) (Ellman's reagent) colour reaction (Crawhall, Saunders, and Thompson, 1964, 1966). The validity of the results obtained on representative specimens was also confirmed by quantitative ion-exchange chromatography with the Technicon automatic amino-acid analyser.

D-Penicillamine hydrochloride (450 mg. eight-hourly) lowered the cystine excretion to less than $100 \mathrm{mg} . / 24 \mathrm{hr}$., determined gravimetrically (the colorimetric method of Crawhall, Saunders, and Thompson $(1964,1966)$ cannot be used during treatment with Dpenicillamine). A diffuse morbilliform rash developed acutely on the eighth day of treatment; this was accompanied by fever $\left(101.2^{\circ}\right.$ F. ; $38.4^{\circ} \mathrm{C}$.) and tachycardia, but there was no lymphadenopathy or splenomegaly. The drug was stopped and prednisolone was given orally (an initial dose of $15 \mathrm{mg}$. followed by $10 \mathrm{mg}$. every eight hours for two days and then $5 \mathrm{mg}$. eight-hourly for two days). D-Penicillamine was resumed after a total lapse of 10 days, and the dose increased in increments of $300 \mathrm{mg} . / 24 \mathrm{hr}$. on successive days. The rash recurred on the third day after prednisolone was stopped. It involved the face and feet only, and was accompanied by a tachycardia but no fever. The administration of D-penicillamine was continued $300 \mathrm{mg}$. every 12 hours, and prednisolone, $10 \mathrm{mg}$. every eight hours, suppressed the rash in 24 hours; the dose of the steroid was gradually diminished and stopped completely after seven days. The rash again recurred on the forearms on the third day after the cessation of prednisolone therapy; when this was reinstituted for a further five days the eruption disappeared within 12 hours. The rash recurred for the third time after two days without steroid cover, and disappeared within 24 hours; pyridoxine ( $200 \mathrm{mg}$. stat. and two $50-\mathrm{mg}$. doses at eight-hourly intervals) was given on this occasion. The patient was discharged from hospital taking $300 \mathrm{mg}$. of D-penicillamine hydrochloride every 12 hours. She was not given any more steroids or pyridoxine, and the rash did not recur. The dose of D-penicillamine was gradually increased to $1,050 \mathrm{mg} . / 24 \mathrm{hr}$. over the course of one month.

The patient conceived in September 1964. Except for some vomiting in the early months the pregnancy proceeded normally to term ; delivery was complicated by transverse arrest of the head, but was effected without undue difficulty. The puerperium was normal. D-Penicillamine $(1,050 \mathrm{mg} . / 24 \mathrm{hr}$.) was continued for the whole 
period of pregnancy and subsequently, but no attempt was made to increase it further. The urinary excretion of cystine, cysteinepenicillamine disulphide, and penicillamine disulphide was measured by ion-exchange chromatography with the Technicon automatic amino-acid analyser, before, during, and after the pregnancy (Table I). The patient's blood urea was $44 \mathrm{mg} . / 100 \mathrm{ml}$. nine days after delivery. Radiological studies performed at this time showed that the calculi were no longer present (Special Plate, Fig. 2), and that the right kidney was small and hydronephrotic.

TABLE I.-Urinary Excretion of Cystine, Cysteine-penicillamine Disulphide, and Penicillamine Disulphide by a Cystinuric Patient Taking $1,050 \mathrm{mg}$. D-Penicillamine Hydrochlonde (=843 mg. D-Penicillamine Base $/ 24 \mathrm{hr}$.) Before and During Pregnancy. Representative Values Before Treatment were $840 \mathrm{mg}$. and $684 \mathrm{mg}$. Cystine $/ 24 \mathrm{hr}$. in Before Treatment
December 1963

\begin{tabular}{|c|c|c|c|c|}
\hline \multirow[b]{2}{*}{ Date } & \multirow{2}{*}{$\begin{array}{c}\text { Approximate } \\
\text { Duration of } \\
\text { Pregnancy }\end{array}$} & \multicolumn{3}{|c|}{ Urinary Excretion (mg./24 hr.) } \\
\hline & & Cystine & $\begin{array}{l}\text { Cysteine- } \\
\text { penicillamine } \\
\text { Disulphide }\end{array}$ & $\begin{array}{l}\text { Penicillamine } \\
\text { Disulphide }\end{array}$ \\
\hline $\begin{array}{c}\text { 7-8 June } 1964 \\
\text { 9-10 Aug. } 1964 \\
\text { 30 Nov.-1 Dec. } 1964 \\
\text { 15-16 Mar. } 1965 \\
10-11 \text { May } 1965 \\
\text { 30-31 May } 1965 \\
\text { 9-10 June } 1965\end{array}$ & $\begin{array}{l}8 \text { weeks } \\
26 " \text { " } \\
36 \quad " \\
38 \\
40 "\end{array}$ & $\begin{array}{l}362 \\
392 \\
460 \\
498 \\
370 \\
304 \\
298\end{array}$ & $\begin{array}{l}405 \\
178 \\
258 \\
246 \\
246 \\
304 \\
307\end{array}$ & $\begin{array}{l}74 \\
30 \\
24 \\
47 \\
46 \\
47\end{array}$ \\
\hline
\end{tabular}

The baby, a normal boy, weighed $5 \mathrm{lb} .13 \mathrm{oz}$. (2.64 kg.) at birth and $5 \mathrm{lb}$. $15 \mathrm{oz}$. $(2.70 \mathrm{~kg}$.) when 9 days old, and was never breastfed. Physical and mental development were normal when he was last seen at the age of 3 months. Specimens of urine passed during the first days of life contained cysteine-penicillamine disulphide and penicillamine disulphide as well as cystine. The results of quantitative amino-acid analyses of the baby's urine with respect to these sulphur-containing amino-acids and the "basic" amino-acids are presented in Table II. Thin-layer chromatograms (Crawhall, Saunders, and Thompson, 1964, 1966) confirmed the presence of cysteine-penicillamine disulphide and penicillamine disulphide in the urine passed during the first days of life; all the specimens studied showed prominent "spots" in the positions of cystine, lysine, and ornithine. Arginine was not detected in any of the specimens by this technique. The later specimens also showed a prominent proline spot, the concentrations of this amino-acid in the urine being $7.84,6.52$, and $4.78 \mathrm{mg} . / 100 \mathrm{ml}$. on 7 June 1965,7 September 1965 , and 20 September 1965, respectively.

TABLE II.-Concentrations of Cystine, Cysteine-penicillamine, Penicillamine Disulphide and the "Basic" Amino-acids in the Urine of an Infant whose Mother was Treated with D-Penicillamine Hydrochloride (1,050 mg./24 hr.) Throughout Pregnancy

\begin{tabular}{|c|c|c|c|c|c|c|}
\hline \multirow{3}{*}{ Age of Infant } & \multicolumn{6}{|c|}{ Amino-acid Concentration (mg./100 ml.) } \\
\hline & \multirow{2}{*}{$<1$ day } & \multirow{2}{*}{2 days } & \multirow{2}{*}{4 days } & \multicolumn{3}{|c|}{3 months } \\
\hline & & & & Specimen 1 & Specimen 2 & Specimen 3 \\
\hline $\begin{array}{ll}\text { Cystine.. } \quad . .\end{array}$ & 1.37 & 3.67 & 1.372 & 3.75 & 3.54 & $2 \cdot 62$ \\
\hline $\begin{array}{l}\text { Cysteine- } \\
\text { penicillamine }\end{array}$ & 1.69 & 1.53 & 0.575 & 0 & 0 & 0 \\
\hline $\begin{array}{l}\begin{array}{l}\text { Penicillamine- } \\
\text { disulphide }\end{array} \\
\text { Ornithine } \\
\text { Lysine } \\
\text { Arginine }\end{array}$ & $\begin{array}{l}0.486 \\
0.801 \\
9 \cdot 73 \\
0.552\end{array}$ & $\begin{array}{c}\text { Trace } \\
1.85 \\
18.7 \\
0.44\end{array}$ & $\begin{array}{c}0.419 \\
1.11 \\
6.15 \\
\text { Trace }\end{array}$ & $\begin{array}{l}0 \\
1.397 \\
27.55 \\
1.00\end{array}$ & $\begin{array}{c}0 \\
1.26 \\
23 \cdot 5 \\
1 \cdot 36\end{array}$ & $\begin{array}{c}0 \\
0.92 \\
19 \cdot 2 \\
0.986\end{array}$ \\
\hline $\begin{array}{l}\text { Total volume } \\
\text { (ml.) }\end{array}$ & 1.3 & 12 & 31 & 96 & 585 & 515 \\
\hline $\begin{array}{l}\text { Length of } \\
\text { collection (hr.) }\end{array}$ & & - & - & 9 & 23 & 20 \\
\hline
\end{tabular}

\section{Discussion}

We consider it very unlikely that stones as large as some of those shown in Fig. 1 would have been passed asymptomatically even though the ureters dilate during pregnancy. The patient had no treatment except D-penicillamine. No alteration occurred in the fluid intake, she maintained a normal diet (cf. Brand, Cahill, and Harris, 1935 ; Lotz and Bartter, 1965), and no alkali was given. The conclusion that $\mathrm{D}$-penicillamine caused stone dissolution in this patient therefore seems inescapable.

The presence of cysteine-penicillamine and penicillamine disulphide in the infant's urine establishes that $\mathrm{D}$-penicillamine and/or these disulphides cross the placental barrier, and the fact that they were still present four days after birth suggests that these "unphysiological" amino-acids may have been present in forms other than simple solution in the tissue fluids. It is of particular interest that foetal development proceeded normally in spite of this alteration in the foetal internal environment throughout gestation.

The pattern of basic amino-acid excretion seen on the thinlayer chromatograms-namely, prominent lysine and ornithine "spots" with no apparent increase in arginine-is compatible with the child being heterozygous for the abnormal gene which causes cystinuria. This is in agreement with our knowledge that the mother is homozygous for the abnormal gene and the father showed no chemical abnormality (Crawhall et al., 1966).

The dose of D-penicillamine was less than that used by McDonald and Henneman (1965), who have also reported cystine stone dissolution during $\mathrm{D}$-penicillamine therapy. We were initially rather cautious about increasing the dose because of the ease with which skin rashes had developed during the earlier stages of treatment. The patient then became pregnant, and, in spite of reports that patients with Wilson's disease had given birth to normal children while taking D-penicillamine (Sherwin, Beck, and McKenna, 1960 ; Boulding, 1961), it was thought prudent to increase the dose no further until after delivery.

The urinary cystine excretion was reduced to about $400 \mathrm{mg}$./ $24 \mathrm{hr}$. (=270 mg./1. or $330 \mathrm{mg}$. $/ \mathrm{g}$. creatinine) on most of the occasions that it was measured (Table I). This concentration of cystine $(270 \mathrm{mg}$./1.) is only just below the solubility limit of cystine in urine at $\mathrm{pH}$ values between 5 and 6.5 (Dent and Senior, 1955), and our practice is to try to keep the cystine excretion below $200 \mathrm{mg} . / 24 \mathrm{hr}$. in adults or in the range 100$150 \mathrm{mg} . / \mathrm{g}$. creatinine in children. Lotz and Bartter (1965) recommended keeping the urinary cystine excretion below 100 mg./g. creatinine and have described the use of simple qualitative tests for this purpose. Thus the present patient received barely adequate treatment according to these chemical criteria, and these considerations make the radiological findings (Special Plate, Figs. 1 and 2) even more striking. It is apparent that her right kidney, although diseased, still excretes radio-opaque dyes, and therefore has a useful degree of residual functional capacity. This may explain why the stone dissolved so rapidly in response to treatment. Conversely, another cystinuric patient under our care (Scowen and Watts, unpublished) has a stone in a very poorly functioning kidney, and this has not dissolved during $\mathrm{D}$-penicillamine therapy. These considerations suggest that $\mathrm{D}$-penicillamine should be used before renal function has become impaired by calculus formation and its complications.

\section{Summary}

A case of cystinuria in which renal calculi had disappeared after 18 months' continuous treatment with D-penicillamine is described. The treatment (approximately $1 \mathrm{~g}$. D-penicillamine hydrochloride per 24 hours) was continued throughout pregnancy without any untoward effect on the mother or foetus.

The results of urinary amino-acid analyses on the mother during pregnancy and on the baby are reported. Cysteinepenicillamine disulphide and penicillamine disulphide were present during the first eight days of life but not when the child was approximately 3 months old.

The control of $D$-penicillamine therapy by measuring the urinary cystine is briefly discussed, as well as the possible relationship between renal function and the therapeutic efficacy of D-penicillamine in promoting the dissolution of renal calculi.

Note.-The child was seen when 1 year old and had continued to progress normally.

We are pleased to acknowledge our indebtedness to the Governors of St. Bartholomew's Hospital for their general research grants; to Mr. Gordon L. Bourne, who undertook the patient's obstetric care ; 
to Mr. L. Rawlings for his technical help ; and to Miss E. Saunders for the thin-layer chromatograms.

\section{REFERENCES}

Bartter, F. C., Lotz, M., Thier, S., Rosenberg, L. E., and Potts, J. T (1965). Ann. intern. Med., 62, $790^{\circ}$

Boulding, J. E. (1961). In Wilson's Disease : Some Current Concepts, edited by J. M. Walshe and J. N. Cumings. Oxford.

Brand, E. Cahill, G. F., and Harris, M. M. (1935). F. biol. Chem., $109,69$.

Crawhall, J. C., Saunders, E. P., Thompson, C. J. (1964). First Meeting of Federation of European Biochemical Societies. Abstract A 117.

- (1966). Ann. hum. Genet., 29, 257.

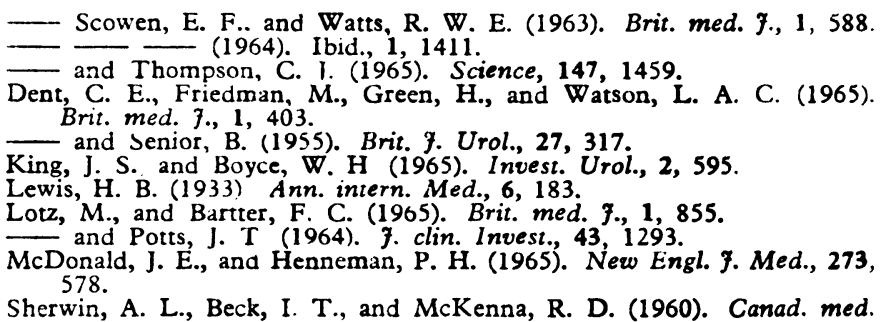

Sherwin, A. L., Beck, I. T., and McKenna, R. D. (1960). Canad. med. Ass. F., 83, 160 .

\title{
Artifact Ulcers and Bone Lesions Produced by Elastic Bands
}

\author{
IAN D. KITCHIN,* M.B., F.R.C.S.ED. ; C. MCGIBBON,† M.D. ; R. H. SEVILLE, $\ddagger$ M.D., M.R.C.P.
}

[With Special Plate]

Brit. med. F., 1967, 2, 218-219

It must be uncommon for ulcers to follow the deliberate use of an elastic band, but for the band to have been lost and recovered at operation must be rare indeed. An extensive search of the literature has revealed no such case, so the two described should be of interest.

\section{Case 1}

The patient was a married woman aged 69 . The family and the past history were positive for varicose veins, and she developed a white leg (left) in 1922 after pregnancy. It was not until 1947 that she produced some ulcers. She was first seen as an outpatient in 1954, when a diagram of irregular-shaped ulcers was made. She defaulted after being told by one of us (R.H. S.) that she would get better only if she would leave them alone. In 1962 a band of ulcers developed fairly suddenly on the lower part of the left leg, and a consultation was sought because of the severity of her pain. During this examination she was asked if an elastic band had been put round the leg, but she resented the question and changed the subject, mentioning the chronic invalidism of her husband and her own inability to work because of the ulcer.

She was subsequently admitted to hospital with three linear ulcers measuring $\frac{1}{3}$ in $(0.8 \mathrm{~cm}$.) wide and about 1 in. $(2.5 \mathrm{~cm}$.) long, placed horizontally round the distal third of the lower part of the left leg. There was pigmentation of the surrounding skin, which was also oedematous, indurated, eczematous, and slightly moist. Secondary eczematous spread was observed on the thighs, forearms, and, to a lesser extent, on the back.

Healing was uneventful, but she still complained of excessive pain on walking, so an $x$-ray examination was arranged, and the opinion of an orthopaedic surgeon (I. D. K.) requested. When seen by him all the ulcers had healed, but the skin over most of the lower third of the leg was of poor quality, thin, and shiny. The foot was oedematous. During the examination it was noted that a very shallow depression in the skin encircled the leg through the healed ulcer area. This was difficult to see, and then only when the light threw a shadow upon it. The groove coincided with the level of the peculiar radiological changes (Special Plate, Figs. 1 and 2). When these were studied it was noted that the depression in and the new bone formation on the tibia and fibula involved certain surfaces only, and these corresponded to the surfaces which would be in contact with an encircling band, like a belt round two pulleys.

In spite of the patient's protests that no encircling band could possibly be present it was decided to explore. This was done through

* Consultant Orthopaedic Surgeon, Lancaster

Consultant Dermatologist, Liverpool.

f Consultant Dermatologist, Liverpool. a postero-lateral approach through the only area of reasonably sound skin. The fibula was exposed and no foreign material was found, but as the bone was thick and rough some was chiselled away, disclosing an elastic band. This was divided and removed without difficulty. Healing of the wound was uneventful, and the patient was discharged from hospital.

Within 10 days a triangular-shaped ulcer had developed just below the original site with scarring, suggestive of a phenol type of burn. On her readmission marked dressings were always altered and coloured ointments removed. The area was then occluded, but further artifact lesions appeared at the edge of the dressing, and when this was extended she attacked her wedding-ring finger with a tight elastic band hidden under the ring. Her attitude was always one of amazement, but the innuendoes showed the underlying resentment. She still has her ulcers.

\section{Case 2}

The patient, a man aged 51, presented first in 1948 with an ulcer almost encircling the lower third of his right leg. He was a mild diabetic, in poor circumstances, and very dirty. It was thought then that the ulcer had been aggravated to gain admission to hospital, where it healed spontaneously in a month. He was next seen in 1958, again with an ulcer of his right leg, which this time completely encircled the limb just above the ankle. The leg had been much constricted but the circulation was good. In 1960 a loop of rubber appeared in the ulcer. It was divided, one end pulled upon, and a rubber band removed. A week later another band was removed under similar circumstances, and yet a third and final one was similarly dealt with at the end of another week. After this the ulcer healed completely in a few weeks, and has remained so. $X$-ray films of this case (Special Plate, Figs. 3 and 4 ) show clearly the grooves in the bone caused by the three bands.

\section{Comment}

Patients with self-inflicted lesions usually hope to gain something from their presence, deny any knowledge of their origin, and cannot be tricked into admission. It is thought that the motivation behind this may well be subconscious. Briefly it may be stated that the lesions are bizarre-shaped and their site is important, as usually the injury is inflicted with the right hand (in right-handed individuals) and so must be within its reach. The appearance of fresh lesions above an occlusive dressing is diagnostic. In Case 1 it transpired that the patient avoided keeping summer visitors, which she resented, by means of the ulcers. Chronicity here is probably due to the very long 
J. C. CRAWHALL ET AL.: DISSOLUTION OF CYSTINE STONES DURING D-PENICILLAMINE TREATMENT
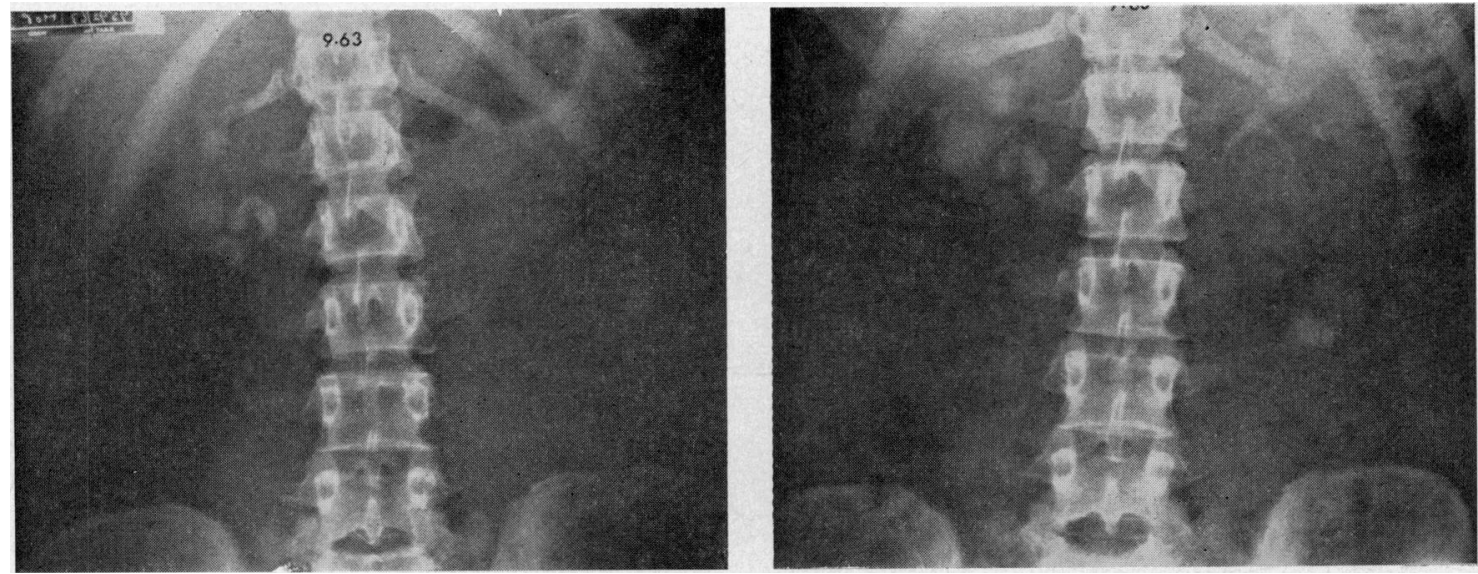

Fig. 1.-Plain abdominal radiograph and intravenous pyelogram before treatment with D-penicillamine.
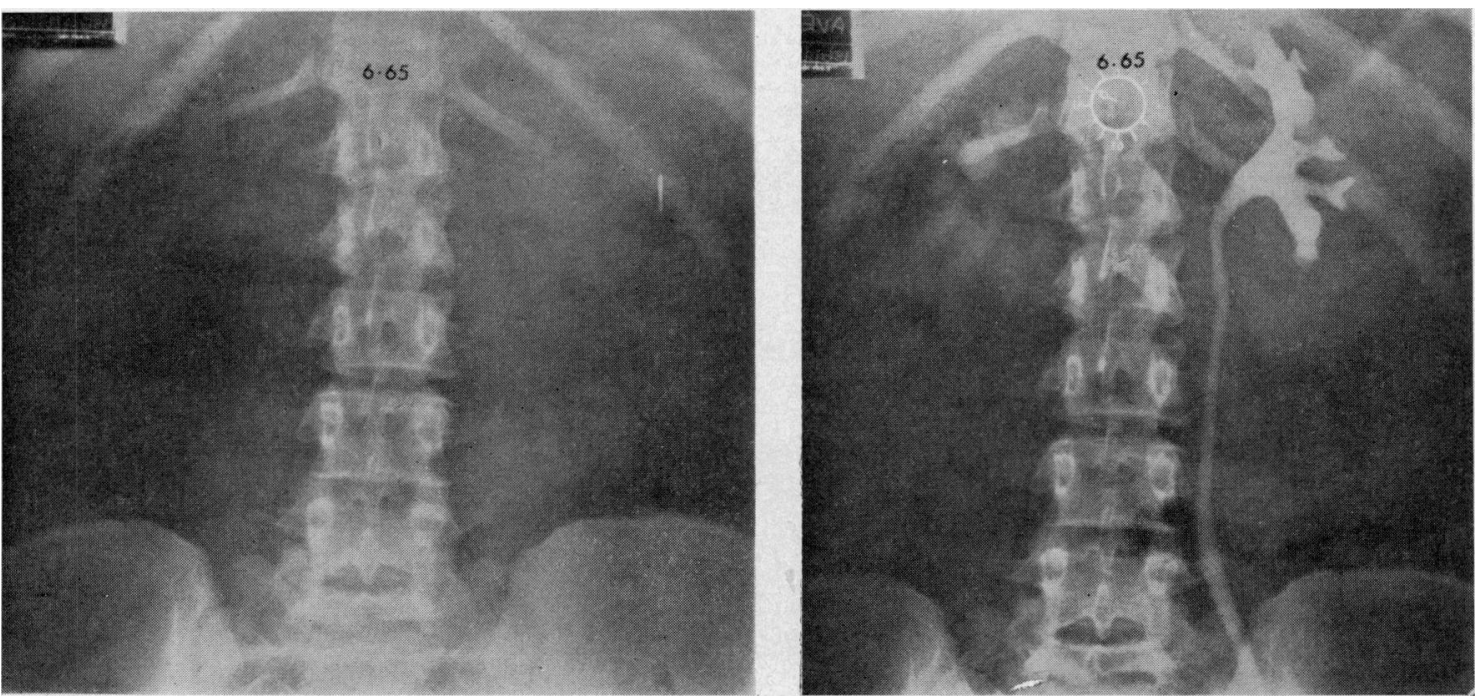

Fig. 2.-Plain abdom-

inal radiograph and intravenous pyelogram after 18 months' treatment with D-penicillamine.

\section{$\because$ A. EBRINGER AND P. COLVILLE: CHLOROQUINE NEUROMYOPATHY}

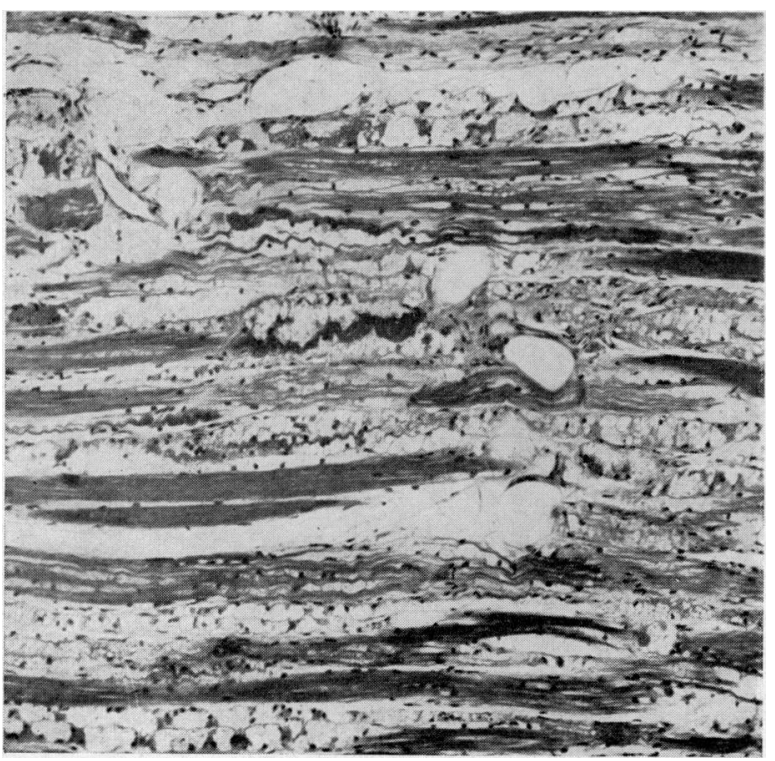

FIG. 2.-Biopsy from the weak left tibialis anterior muscle: there is replacement of a large proportion of the sarcoplasm by vacuoles and only occasional myofibrils are intact. (H. and

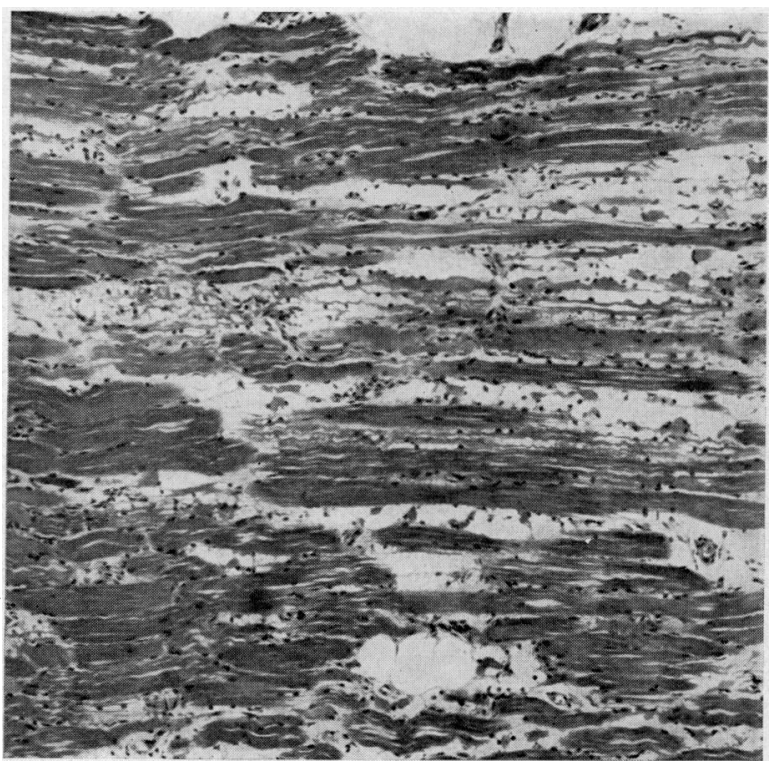

Fig. 3.-Biopsy from the left tibialis anterior muscle three Fig. 3.-Biopsy from the left tibialis anterior muscie three returned : there is almost complete disappearance of vacuoles and there are more intact muscle fibres than in the previous biopsy. (H. and $\mathrm{E}$. $\times$ 75.) 